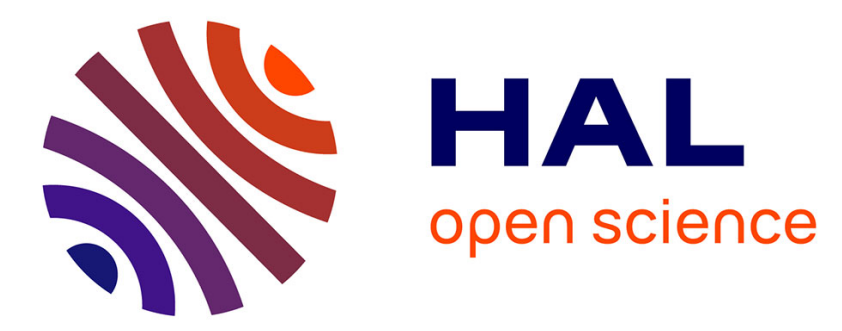

\title{
On the reaction mechanism of $\mathrm{MnOx} / \mathrm{SAPO}-34$ bifunctional catalysts for the conversion of syngas to light olefins
}

C. Coudercy, V. L'Hospital, R. Checa, A. Le Valant, P. Afanasiev, S. Loridant

\section{- To cite this version:}

C. Coudercy, V. L'Hospital, R. Checa, A. Le Valant, P. Afanasiev, et al.. On the reaction mechanism of $\mathrm{MnOx} / \mathrm{SAPO}-34$ bifunctional catalysts for the conversion of syngas to light olefins. Catalysis Science \& Technology, 2021, 10.1039/d1cy01673c . hal-03476782

\section{HAL Id: hal-03476782 \\ https://hal.science/hal-03476782}

Submitted on 13 Dec 2021

HAL is a multi-disciplinary open access archive for the deposit and dissemination of scientific research documents, whether they are published or not. The documents may come from teaching and research institutions in France or abroad, or from public or private research centers.
L'archive ouverte pluridisciplinaire HAL, est destinée au dépôt et à la diffusion de documents scientifiques de niveau recherche, publiés ou non, émanant des établissements d'enseignement et de recherche français ou étrangers, des laboratoires publics ou privés. 
On the reaction mechanism of $\mathrm{MnOx} / \mathrm{SAPO}-34$ bifunctional catalysts for the conversion of syngas to light olefins

Christophe Coudercy, ${ }^{\mathrm{a}}$ Valentin L'hospital, ${ }^{\mathrm{b}}$ Ruben Checa, ${ }^{\mathrm{a}}$ Anthony Le Valant, ${ }^{\mathrm{b}}$ Pavel Afanasiev ${ }^{\mathrm{a}}$ and Stéphane Loridant ${ }^{\mathrm{a}, *}$

$\mathrm{MnO}_{\mathrm{x}} / \mathrm{SAPO}$-34 bifunctional catalysts are efficient for the conversion of syngas to light olefins. However, the reaction mechanism is still debated in particular the nature of the intermediate formed on $\mathrm{MnO}_{\mathrm{x}}$ (ketene vs methanol). In this study, it was evidenced from catalytic data and in situ DRIFT measurements that methanol is a key reaction intermediate produced on MnOx that synergistically reacts with SAPO-34 to produce light olefins.

Light olefins $\left(\mathrm{C}_{2}-\mathrm{C}_{4}\right)$ are key building-block chemicals to produce plastics, medicines and paints. They are presently produced worldwide in huge amounts (exceeding $150 \mathrm{Mt}^{-1} \mathrm{y}^{-1}$ ) mostly by steam cracking of naphta which is highly energy-consuming process. Alternative eco-efficient processes such as oxidative dehydrogenation of light alkanes, dehydration of bio-alcohols are attractive, but the former suffers from both low selectivity at high conversion and process limitations ${ }^{1}$ and the latter from both insufficient catalyst stability and costly lignocellulose biorefineries. ${ }^{2-5}$

Syngas-based processes will become more attractive in the future since renewable carbon resources (biomass, wastes, $\mathrm{CO}_{2}$ ) are expected to gradually replace fossil fuels. ${ }^{6}$ A two-step process including methanol synthesis followed by methanol-to-olefins (MTO) process is commercially available to produce light olefins but development of a more energetically and costly-efficient direct process is needed. ${ }^{7}$ In spite of important progresses, the direct Fischer-Tropsch to Olefins (FTO) process is limited by the Anderson-Schultz-Flory (ASF) distribution and the maximal selectivity to $\mathrm{C} 2-\mathrm{C} 4$ hydrocarbons is around $60 \%{ }^{6-9}$

Few years ago, a composite catalyst obtained by physically mixing a reducible metal oxide $\left(\mathrm{ZnCrO}_{\mathrm{x}}\right)$ and a zeotype (MSAPO) enabled direct conversion of syngas to light olefins giving a selectivity to light olefins (excluding $\mathrm{CO}_{2}$ ) as high as $80 \%$ at a $\mathrm{CO}$ conversion of $17 \%$, wellsurpassing the limit predicted by the ASF distribution model via the FTO route. ${ }^{8,9}$ This combination of an oxide and a zeotype was called OXZEO by Jiao et al. ${ }^{8}$ A high selectivity to light olefins (74\%) at a conversion of $11 \%$ was reported the same year using $\mathrm{ZnZrOx}$ oxide instead of $\mathrm{ZnCrO}_{\mathrm{x}}$ and 
different reaction conditions. ${ }^{10}$ Since then, numerous other metal oxide-zeotype combinations yielding a high selectivity to light olefins have been reported and this concept was recently reviewed. ${ }^{7,9}$ It is designed in the literature either by OXZEO or more generally by STO (syngas to olefins). Most of oxides contained $\mathrm{Zn}: \mathrm{ZnO}^{11} \mathrm{ZnCrO}_{\mathrm{x}},{ }^{8,12-19} \mathrm{ZnZrO}_{\mathrm{x}},{ }^{10,20,21} \mathrm{ZnAlO}{ }^{22-24} \mathrm{Zr}$ promoted $\mathrm{ZnAlO}_{\mathrm{x}}{ }^{25} \mathrm{La}$-doped $\mathrm{ZnAlO}_{\mathrm{x}}{ }^{26} \mathrm{Zn}$ spinels, ${ }^{27} \mathrm{ZnCeZrO}_{\mathrm{x}}{ }^{28-31}$ Alternatively, $\mathrm{MnO}_{\mathrm{x}}{ }^{32}$ $\mathrm{MnGaO}_{\mathrm{x}},{ }^{33,34}$ or $\mathrm{ZrInO}_{\mathrm{x}},{ }^{35}$ was used. The zeotype corresponded most of the time to SAPO-34 (microporous, microsized) or to mesoporous M-SAPO, ${ }^{8,11,32}$ hierarchical SAPO-34, ${ }^{21}$ nanosized SAPO-34, ${ }^{12,25}$ SAPO-18, ${ }^{13,18}$ SAPO-35, ${ }^{18}$ various SAPOs, ${ }^{24}$ AlPO-18, ${ }^{36}$ SSZ-13, ${ }^{17,20}$. Finally, note that a 1000 t. $^{-1}$ industrial pilot plant was built in Shaanxi, China. ${ }^{9}$

The reaction mechanism leading to light olefins is still debated: ${ }^{7,9}$ on one hand, the Xinhe Bao's group proposed that $\mathrm{CO}$ is activated through the Boudouard reaction (disproportionation to $\mathrm{CO}_{2}$ and adsorbed $\mathrm{C}^{*}$ ) on reduced metal oxide surfaces. $\mathrm{CH}_{2}$ species are formed by direct reaction of $\mathrm{C}^{*}$ with $\mathrm{H}_{2}$ and then react with $\mathrm{CO}$ to produce $\mathrm{CH}_{2} \mathrm{CO}$ (i.e. ketene) as an intermediate, ${ }^{8,9,32,33}$ which subsequently diffuses into the zeotype to form lower olefins by $\mathrm{C}-\mathrm{C}$ coupling. ${ }^{9,37} \mathrm{CH}_{4}$ is formed by reaction of $\mathrm{CH}_{2}$ species and $\mathrm{H}_{2}$. On the other hand, methanol and dimethyl ether (DME) formation in significant amounts was evidenced over $\mathrm{ZnO},{ }^{10} \mathrm{ZnZrO}_{\mathrm{x}},{ }^{10,20} \mathrm{ZnAlO}_{\mathrm{x}},{ }^{22,23}, \mathrm{Zn}$ spinels ${ }^{27}$ and $\mathrm{ZrInO}_{\mathrm{x}}{ }^{35} \mathrm{In}$ this case, non-dissociative activation of $\mathrm{CO}$ leads to formates and methoxy species as shown by in situ DRIFT measurements. ${ }^{20,27,31}$ Light olefins are then produced over the zeotype similarly to the MTO process and methane arises from consecutive methanol decomposition by CO cleavage on oxygen vacancies. ${ }^{35}$ Therefore, further studies on the reaction mechanism are needed. Anyway, the key intermediates (ketene versus methanol) may vary with metal oxides and reaction conditions $^{9}$ and both mechanisms could occur in parallel. ${ }^{38}$

As regards $\mathrm{MnOx} / \mathrm{SAPO}-34$ bifunctional catalysts, ketene was assumed to be the key intermediate ${ }^{32}$ by analogy with $\mathrm{ZnCrO}_{\mathrm{x}}{ }^{8}$ and possibly because the selectivity to methanol and DME was lower than $0.5 \%$ in the reaction conditions. Note that $\mathrm{MnOx}$ tested alone led to ca $50 \%$ of methane which is much higher than when SAPO-34 is added. ${ }^{32}$ In situ DRIFT measurements achieved at room temperature (RT) on MnO after pre-treatments $\left(\mathrm{H}_{2}\right.$ or $\left.\mathrm{N}_{2}\right)$ at various temperatures and adsorption of $\mathrm{CO}$ at $\mathrm{RT}$ revealed formation of carbonates. The characteristic $(\mathrm{C}-\mathrm{H})$ stretching bands of formate species typically at 2840-2845 and 2945-2950 $\mathrm{cm}^{-1}$ were not observed. ${ }^{32}$

In this paper, a new insight into the reaction mechanism of $\mathrm{MnO}_{\mathrm{x}} / \mathrm{SAPO}-34$ bifunctional catalysts is provided from catalytic performances and in situ DRIFT measurements achieved on MnOx alone and on $\mathrm{MnO}_{\mathrm{x}} / \mathrm{SAPO}-34$ mechanical mixtures. 
As in the reference study, ${ }^{32} \mathrm{MnO}_{\mathrm{x}}$ was obtained from $\mathrm{MnCO}_{3}$ (see details in the Supporting Information). Its BET surface area was $23 \mathrm{~m}^{2} \cdot \mathrm{g}^{-1}$. A single $\mathrm{MnO}$ manganosite phase with a crystallite size of $21 \mathrm{~nm}$ was evidenced from XRD (Fig. S1). Its However, Raman spectroscopy revealed the presence of $\mathrm{Mn}_{3} \mathrm{O}_{4}$ (bands at 318, 370 and $656 \mathrm{~cm}^{-1}$ ) ${ }^{39-41}$ in addition to $\mathrm{MnO}$ feature around $550 \mathrm{~cm}^{-1} \cdot{ }^{42-44} \mathrm{Mn}_{3} \mathrm{O}_{4}$ is probably present as an amorphous or nanocrystalline overlayer ${ }^{45}$ formed upon exposure to air at RT. $\mathrm{Mn}_{3} \mathrm{O}_{4}$ becomes more crystallized upon increasing the temperature to $360{ }^{\circ} \mathrm{C}$ under $10 \% \mathrm{H}_{2}-\mathrm{N}_{2}$ flow (thinner bands in Fig. S2) before disappearing at higher temperatures. Then, the spectra contained mainly two broad bands at 546 and $626 \mathrm{~cm}^{-1}$. The former was attributed to the 2TO (Transverse Optical) or LO (Longitudinal Optical) mode of $\mathrm{MnO}^{42-44}$ while the other one is not observed for single crystals. Its observation could be related to the nanocrystallinity and/or non-stoichiometry $\left(\mathrm{MnO}_{1 \pm} \quad\right.$. Furthermore, the IR bands at 3680, 3630 $\mathrm{cm}^{-1}$ and $863 \mathrm{~cm}^{-1}$ observed in the in situ DRIFT spectra of $\mathrm{MnO}_{\mathrm{x}}$ under $\mathrm{H}_{2}$ flow between 380 and $450{ }^{\circ} \mathrm{C}$ (Fig. S3) were attributed to surface hydroxyl ${ }^{46}$ and carbonated species, ${ }^{47-48}$ respectively. Activation of $\mathrm{MnO}_{\mathrm{x}}$ under $\mathrm{H}_{2}$ flow at $410{ }^{\circ} \mathrm{C}$ enabled to absorb $\mathrm{CO}$ at $-2{ }^{\circ} \mathrm{C}$ as revealed by observation of IR bands at 2062, 2038, 1984, 1962, 1927 and $1917 \mathrm{~cm}^{-1}$ (Fig. S4) corresponding to $\mathrm{Mn}_{\mathrm{y}}(\mathrm{CO})_{\mathrm{x}}$ species. ${ }^{49-51}$ However, no adsorption was evidenced after activation under He at the same temperatures showing that the $\mathrm{Mn}_{3} \mathrm{O}_{4}$ passivation layer does not adsorb $\mathrm{CO}$. It was concluded that reduction of $\mathrm{Mn}_{3} \mathrm{O}_{4}$ leads to formation of oxygen vacancies at the surface of $\mathrm{MnO}_{\mathrm{x}}$ able to adsorb CO. Note that no signals corresponding to linearly absorbed CO were previously observed on both fresh sample and those reduced at different temperatures. ${ }^{32}$

As shown in Table $1, \mathrm{MnO}_{\mathrm{x}}$ activated under $\mathrm{H}_{2}$ led to a $\mathrm{CO}$ conversion of $2.5 \%$ with a high selectivity ( $>30 \%$ ) to $\mathrm{CO}_{2}$ and $\mathrm{CH}_{4}$. Interestingly, a significant selectivity to $\mathrm{CH}_{3} \mathrm{OH}(8.1 \%)$ was determined. The other by-products were $\mathrm{C} 2+$ hydrocarbons with an $\mathrm{O} / \mathrm{P}$ (olefins to paraffins) ratio of 1.47 and traces of DME.

SAPO-34 was synthetized by a hydrothermal method (see details in the SI) and a microcrystalline powder was obtained after calcination (see XRD diagram in Fig. S5 and SEM image in Fig. S6). Its framework composition was $\mathrm{Si} / \mathrm{Al} / \mathrm{P}: 0.14 / 1 / 0.66$. The solid was mostly microporous since its BET surface area was $461 \mathrm{~m}^{2} \cdot \mathrm{g}^{-1}$ while the microporous one was $397 \mathrm{~m}^{2} \cdot \mathrm{g}^{-1}$, the difference between the two values $\left(64 \mathrm{~m}^{2} . \mathrm{g}^{-1}\right)$ corresponding to the mesoporous one due to intergranular porosity. Its microporous volume was $0.19 \mathrm{~cm}^{3} \cdot \mathrm{g}^{-1}$.

The catalytic tests were carried out using different arrangements of SAPO-34 and $\mathrm{MnO}_{\mathrm{x}}$ layers in a catalytic bed (see details in the SI and Table.S1), in order to vary the degree of contact between the two functions. In the separated double layer (SDL), the layers of MnOx and SAPO-34 were 
separated by a SiC inert layer, so the interaction between the two phases was the smallest. Then the contact progressively increased in the simple double layer (DL), triple layer (MLx3) and quadruple layer (MLx4) bed.

Table 1 Catalytic data obtained for $\mathrm{MnO}_{x}, \mathrm{MnO}_{\mathrm{x}} / \mathrm{SAPO}-34$ separated double layer (SDL), double layer (DL) and Multi-Layer (ML) catalytic beds. Reaction conditions: $\mathrm{m}(\mathrm{MnOx})=600 \mathrm{mg}$, $\mathrm{m}(\mathrm{SAPO}-34)=300 \mathrm{~g}, \mathrm{P}=25 \mathrm{bar}, \mathrm{T}=410^{\circ} \mathrm{C}, \mathrm{H}_{2} / \mathrm{CO} / \mathrm{Ar}=63.8 / 25.6 / 10.6, \mathrm{WHSV}=87 \mathrm{~mL} \cdot \mathrm{min}^{-1} \cdot \mathrm{g}^{-1}$.

Selectivity value $(\%)$

\begin{tabular}{ccccccccccccccc}
\hline Sample & $\mathrm{X}_{\mathrm{CO}}(\%)^{\mathrm{a}}$ & $\mathrm{O} / \mathrm{P}^{\mathrm{b}}$ & $\mathrm{CO}_{2}$ & $\mathrm{CH}_{4}$ & $\mathrm{CH}_{3} \mathrm{OH}$ & $\mathrm{DME}$ & $\mathrm{C} 2=$ & $\mathrm{C} 2$ & $\mathrm{C} 3=$ & $\mathrm{C} 3$ & $\mathrm{C} 4=$ & $\mathrm{C} 4$ & $\mathrm{C} 5=$ & $\mathrm{C} 5$ \\
\hline MnOx & 2.5 & 1.47 & 32.8 & 37.8 & 8.1 & 0.5 & 4.1 & 4.8 & 2.9 & 1.9 & 5.0 & 0.7 & 0.5 & 1.1 \\
$\mathrm{SDL}$ & 2.6 & 1.66 & 34.5 & 32.3 & 1.2 & 0 & 6.7 & 5.7 & 6.6 & 4.5 & 6.4 & 1.7 & 0.4 & 0.2 \\
$\mathrm{DL}$ & 3.3 & 1.33 & 38.1 & 24.4 & 0.9 & 0 & 7.3 & 5.9 & 8.1 & 7.3 & 5.6 & 2.1 & 0.3 & 0.2 \\
$\mathrm{MLx} 3$ & 4.6 & 2.04 & 37.4 & 18.5 & 2.3 & 5.4 & 9.5 & 4.4 & 10.2 & 5.0 & 4.5 & 2.0 & 0.3 & 0.6 \\
$\mathrm{MLx} 4$ & 4.7 & 1.31 & 37.8 & 18.5 & 0.8 & 0 & 8.3 & 6.5 & 11.5 & 8.8 & 4.2 & 2.9 & 0.3 & 0.3 \\
\hline
\end{tabular}

a: CO conversion,

${ }^{\mathrm{b}}$ : olefins to paraffins molar ratio.

Addition of SAPO-34 to $\mathrm{MnO}_{\mathrm{x}}$ as a separated double layer (see SDL in Table 1) led to a drastic decrease in the $\mathrm{CH}_{3} \mathrm{OH}$ selectivity (and to a lesser extent, in the $\mathrm{CH}_{4}$ one) while the selectivity to $\mathrm{C} 2$ + hydrocarbons and the $\mathrm{O} / \mathrm{P}$ ratio were significantly increased. This trend was emphasized increasing proximity between $\mathrm{MnO}_{\mathrm{x}}$ and SAPO-34 as shown by the data obtained for double layer and multi-layer catalytic beds (DL, MLx3, MLx4 in Table 1). Furthermore, the CO conversion increased which can be explained by a synergistic effect between $\mathrm{MnO}_{\mathrm{x}}$ and SAPO-34. The slight increase in the $\mathrm{CO}_{2}$ selectivity could arise from production of higher amount of $\mathrm{H}_{2} \mathrm{O}$ favouring the water-gas shift reaction. The decrease in the $\mathrm{CH}_{4}$ selectivity agrees with a limitation of consecutive hydrogenation of $\mathrm{CH}_{3} \mathrm{OH}^{35}$ over $\mathrm{MnO}_{x}$ when SAPO-34 is available to transform $\mathrm{CH}_{3} \mathrm{OH}$ into $\mathrm{C} 2+$ hydrocarbons. Note that the decrease in the $\mathrm{O} / \mathrm{P}$ ratio was due to the increase in $\mathrm{CO}$ conversion as paraffins are consecutively produced from olefins by hydrogenation. ${ }^{32}$ Interestingly, the presence of an additional $\mathrm{MnO}_{\mathrm{x}}$ layer in the lower part of the catalytic bed led to much higher amounts of DME and $\mathrm{CH}_{3} \mathrm{OH}$ (compared MLx3 and DL in Table 1) confirming these compounds are reaction intermediates. 
The catalytic properties of $\mathrm{MnO}_{\mathrm{x}} / \mathrm{SAPO}-34$ mechanical mixtures were also determined and the influence of SAPO-34 addition was investigated for its variable proportion. No significant difference of catalytic performances was observed activating the catalysts under $\mathrm{H}_{2}$ flow from 410 to $450{ }^{\circ} \mathrm{C}$ (Fig. S7). For these measurements, $\mathrm{CH}_{3} \mathrm{OH}$ and DME were not analyzed as their amounts were assumed to be low. ${ }^{32}$ The reaction conditions were similar in spite of a lower $\mathrm{H}_{2} / \mathrm{CO}$ ratio (2.0 instead of 2.5). Again, a low $\mathrm{CO}$ conversion was obtained with $\mathrm{MnO}_{\mathrm{x}}$ alone and the main products were $\mathrm{CH}_{4}$ and $\mathrm{CO}_{2}$. The $\mathrm{CO}$ conversion linearly increased (Fig. S8a) with the contact time while the selectivity values remained unchanged (Fig. $\mathrm{S} 8 \mathrm{~b}$ ). However, the $\mathrm{O} / \mathrm{P}$ ratio decreased increasing the $\mathrm{CO}$ conversion (Fig. S8a) indicating that paraffins were consecutively formed from olefins.

As shown in Fig. 1, addition of only 5\% of SAPO-34 strongly increased the CO conversion and drastically increased the $\mathrm{C} 2-\mathrm{C} 4$ selectivity at the expense of $\mathrm{CH}_{4}$ whereas the $\mathrm{CO}_{2}$ selectivity remained similar.
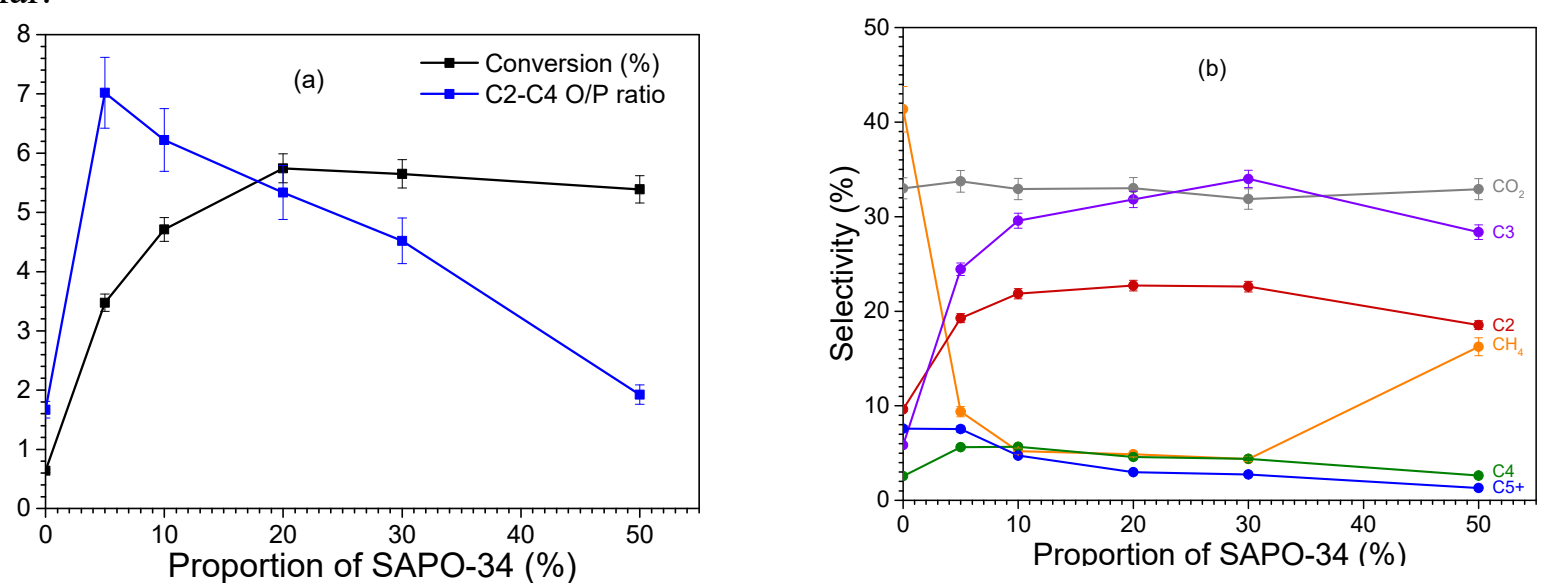

Fig.1 (a) Evolution of the conversion and the $\mathrm{C} 2-\mathrm{C} 4 \mathrm{O} / \mathrm{P}$ ratio and (b) Evolution of the selectivity values with the proportion of SAPO-34. Reaction conditions: $\mathrm{m}(\mathrm{MnOx}+\mathrm{SAPO}-34)=300 \mathrm{mg}, \mathrm{P}=25$ bar, $\mathrm{T}=410{ }^{\circ} \mathrm{C}, \mathrm{H}_{2} / \mathrm{CO} / \mathrm{Ar}=60 / 30 / 10, \mathrm{WHSV}=87 \mathrm{~mL} \cdot \mathrm{min}^{-1} \cdot \mathrm{g}^{-1}$.

It suggests that all these products are formed from the same reaction intermediate via two competitive routes. These trends were confirmed upon increasing the proportion of SAPO-34 up to 20-30\%, but the values were almost constant for higher zeotype amounts. Interestingly, an optimal O/P ratio of 7 was obtained for $5 \%$ of SAPO-34 suggesting that, as the hydrogenation properties of $\mathrm{MnOx}$, the acidity of the zeotype plays a significant role in the consecutive hydrogenation of olefins. ${ }^{13,21,27}$ 
The evolution of in situ DRIFT spectra recorded over time at $-2{ }^{\circ} \mathrm{C}$ under $20 \mathrm{~mL} \cdot \mathrm{min}^{-1}$ of $2.5 \% \mathrm{CO}-\mathrm{He}$ flow is plotted in Fig.2: the bands corresponding to $\mathrm{Mn}_{\mathrm{x}}(\mathrm{CO})_{\mathrm{y}}$ species were observed immediately and they increased for the first $12 \mathrm{~min}$ before being strongly decreased afterwards. At the same time, additional bands rose between 900-1100 $\mathrm{cm}^{-1}$ and 1200-1700 $\mathrm{cm}^{-1}$. Those bands were attributed to 1 and 3 vibrations, respectively of monodentate, chelating bridging and bridging bidentate carbonates. ${ }^{47}$ Note that the splitting of the degenerate 3 vibration (E mode for free carbonate with $\mathrm{D}_{3 \mathrm{~h}}$ symmetry) is typical of each species and that the 1 vibration is slightly IR active due to the loss of symmetry compared to $\mathrm{D}_{3 \mathrm{~h}} .^{47}$ The intensity of carbonate bands continued to grow after $12 \min$ when $\mathrm{Mn}_{\mathrm{x}}(\mathrm{CO})_{\mathrm{y}}$ species began to disappear. Formation of carbonates species over activated $\mathrm{MnO}_{\mathrm{x}}$ was already reported by $\mathrm{Zhu}$ et al. and attributed to the Boudouart reaction. ${ }^{32}$ Note that this exothermic reaction is thermodynamically favorable but could be kinetically limited at $-2{ }^{\circ} \mathrm{C}$. Alternatively, it would imply a redox mechanism during which lattice oxygen is consumed to form carbonates and electrons $\left(\mathrm{CO}+2 \mathrm{O}^{2-} \rightarrow \mathrm{CO}_{3}{ }^{2-}+2 \mathrm{e}^{-}\right)$leading to reduction of $\mathrm{MnO}_{\mathrm{x}}$. Finally, it was confirmed that carbonates are stable ${ }^{32}$ since they were still observed flowing He at $200^{\circ} \mathrm{C}$.

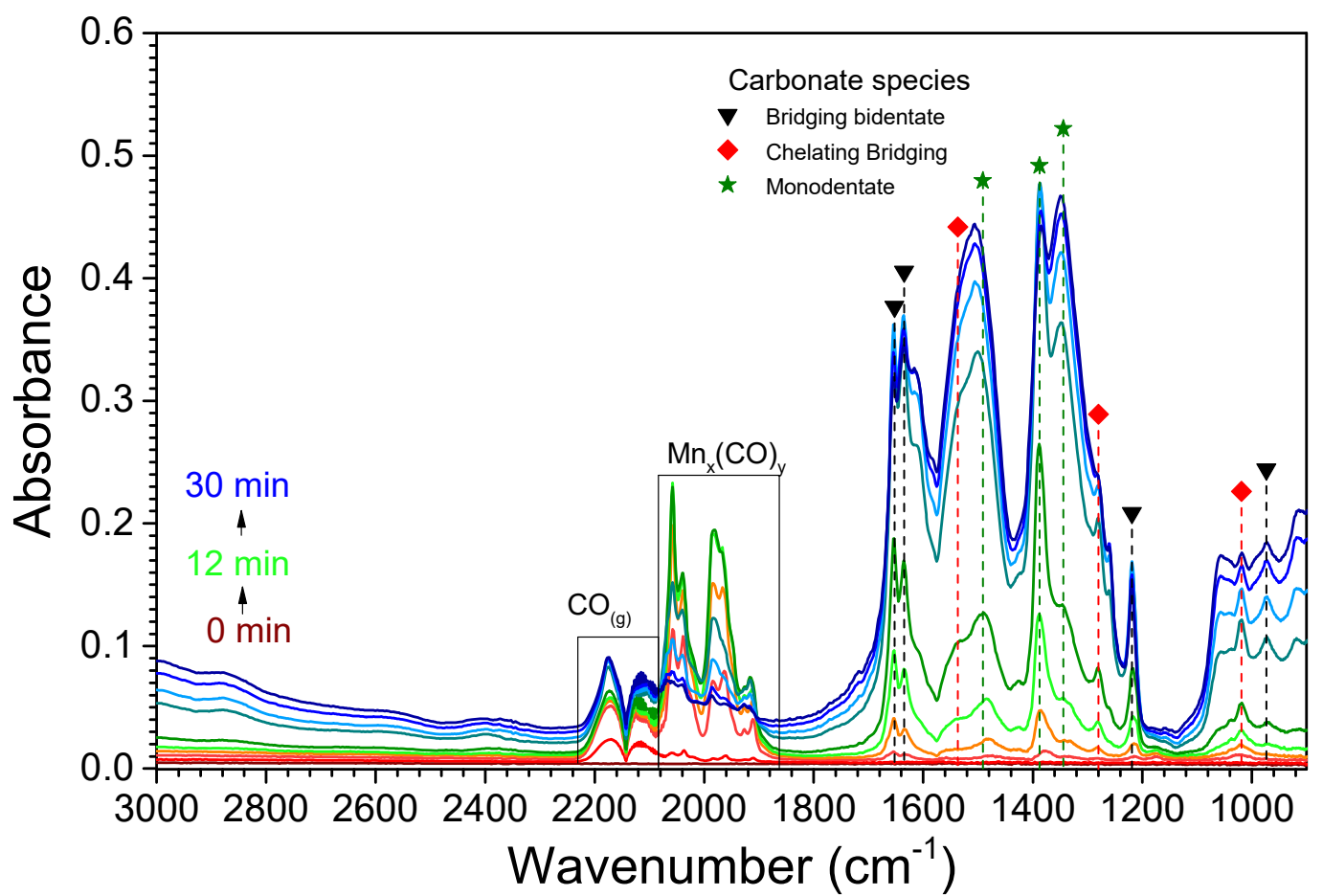

Fig.2 In situ DRIFT spectra of $\mathrm{MnO}_{\mathrm{x}}$ sample recorded over time for $30 \mathrm{~min}$ at $-2{ }^{\circ} \mathrm{C}$ under 20 $\mathrm{mL} \cdot \mathrm{min}^{-1}$ of $2.5 \% \mathrm{CO}-\mathrm{He}$ flow. The background corresponded to the spectrum recorded under 20 $\mathrm{mL} \cdot \mathrm{min}^{-1}$ of $\mathrm{He}$ flow at $-2{ }^{\circ} \mathrm{C}$ after activation at $430{ }^{\circ} \mathrm{C}$ under $20 \mathrm{~mL} \cdot \mathrm{min}^{-1} \mathrm{H}_{2}$ flow for $30 \mathrm{~min}$.

Furthermore, we carried out in situ DRIFT experiments under $\mathrm{H}_{2} / \mathrm{CO}$ flow at the reaction temperature. The spectral evolution of $\mathrm{MnO}_{\mathrm{x}}$ sample recorded over time at $410{ }^{\circ} \mathrm{C}$ under $20 \mathrm{~mL} \cdot \mathrm{min}^{-1}$ of $2.5 \% \mathrm{CO} / 7.5 \% \mathrm{H}_{2} / 90 \% \mathrm{He}$ flow is plotted in Fig. 3: some bands typical of formate species were 
unambiguously observed at 2820 and $2715 \mathrm{~cm}^{-1}(\quad(\mathrm{C}-\mathrm{H})$ and $\quad \mathrm{s}(\mathrm{O}-\mathrm{C}-\mathrm{O})+(\mathrm{C}-\mathrm{H})$, respectively $) .{ }^{52-54}$ These formate bands rose for $10 \mathrm{~min}$ and then remained constant. Furthermore, bands observed around 2143 and $2349 \mathrm{~cm}^{-1}$ were attributed to $\mathrm{CO}$ and $\mathrm{CO}_{2}$ molecules in the gas phase, respectively. ${ }^{48,55}$ As for CO adsorption at $-2{ }^{\circ} \mathrm{C}$, numerous bands were observed at $1700-1200 \mathrm{~cm}^{-1}$. They could either be attributed to formates, ${ }^{52-}$ ${ }^{54}$ or to carbonates. ${ }^{47}$ Furthermore, the bands at $1060,988 \mathrm{~cm}^{-1}$ could also correspond to these species as well as methoxy ones. ${ }^{56-58}$ However, as all these bands evolved with the same rate as the bands at 2820 and $2715 \mathrm{~cm}^{-1}$, they were attributed to formates. In particular, the bands at 1651 and 1614 corresponded to as $(\mathrm{O}-\mathrm{C}-\mathrm{O})$ vibrations, the ones at $1384,1353 \mathrm{~cm}^{-1}$ to $\quad \mathrm{s}(\mathrm{O}-\mathrm{C}-\mathrm{O})$ and $\quad(\mathrm{OC}-\mathrm{H})$ and the ones at 1060, 988 $\mathrm{cm}^{-1}$ to $(\mathrm{OC}-\mathrm{H}) .{ }^{59}$ Formate species have been reported as intermediates leading to methanol formation. ${ }^{20,27,31}$ However, the ${ }_{\text {as }}\left(\mathrm{CH}_{3}\right)$ band at $2900-2900 \mathrm{~cm}^{-1}$ 56-58 typical of methoxy species was not observed in the DRIFT spectra. This feature was explained by a slower formation rate of methoxy species from formates compared to the formation rate of formates and methanol ${ }^{7}$

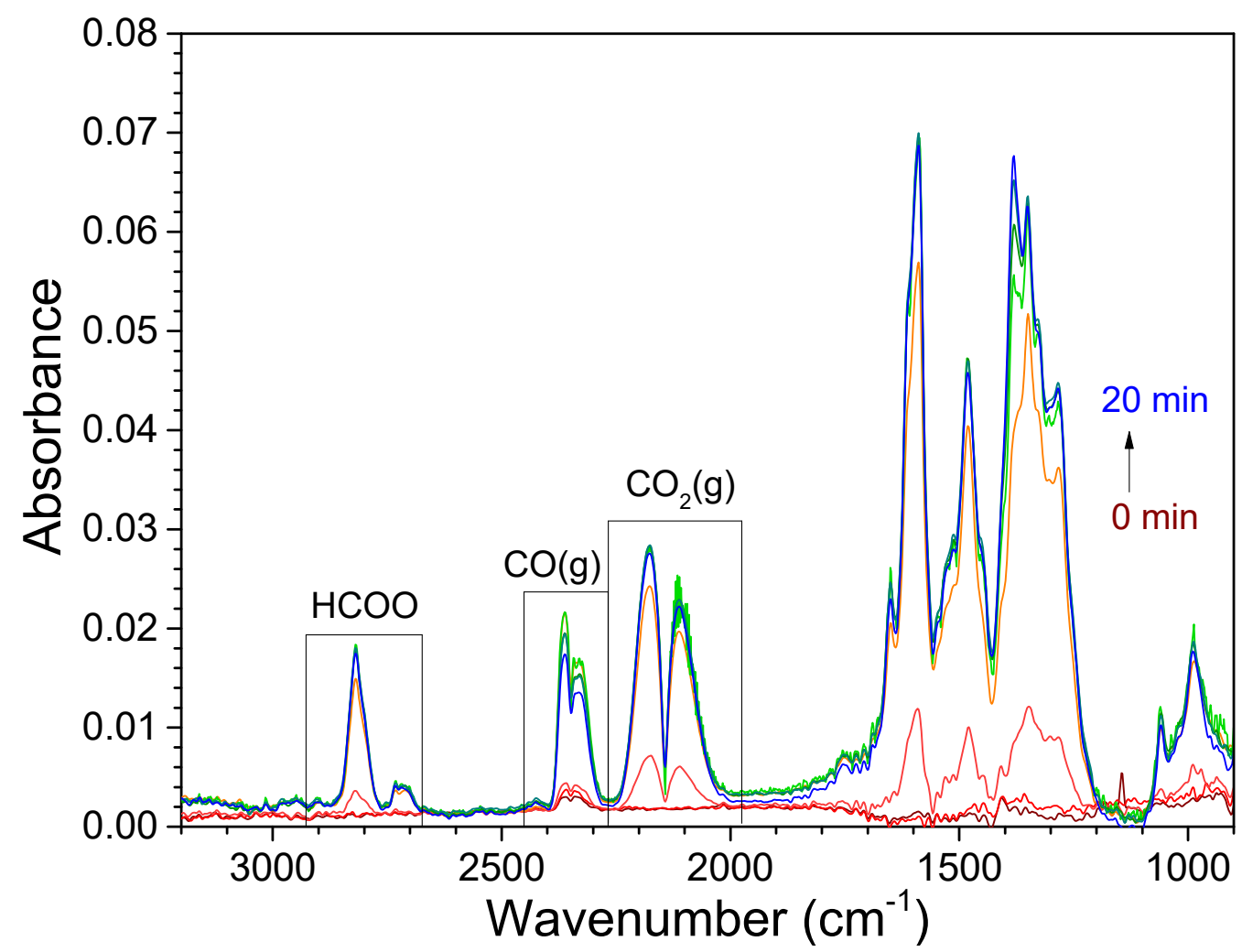

Fig.3 In situ DRIFT spectra of $\mathrm{MnO}_{\mathrm{x}}$ sample recorded over time at $410{ }^{\circ} \mathrm{C}$ under $20 \mathrm{~mL} \cdot \mathrm{min}^{-1}$ of $2.5 \% \mathrm{CO} / 7.5 \% \mathrm{H}_{2} / 90 \% \mathrm{He}$ flow. The background corresponded to the spectrum recorded under 20 $\mathrm{mL} \cdot \mathrm{min}^{-1}$ of $\mathrm{He}$ flow at $410{ }^{\circ} \mathrm{C}$ after activation at $430{ }^{\circ} \mathrm{C}$ under $20 \mathrm{~mL} \cdot \mathrm{min}^{-1} \mathrm{H}_{2}$ flow for $30 \mathrm{~min}$. 
Addition of only $10 \% \mathrm{wt}$. of SAPO-34 to $\mathrm{MnO}_{\mathrm{x}}$ led to a drop of absorbance of formates bands by 2 times whereas after addition of $25 \%$ wt. of SAPO-34, the formates bands became by 4 times less intense (Fig.4). This evidenced a strong decrease of the steady state concentration of formate species caused by addition of zeotype, probably due to methanol conversion over SAPO-34. For the $75 \% \mathrm{MnO}_{\mathrm{x}}-25 \% \mathrm{SAPO}-34$ sample, formates were re-stabilized after decreasing the temperature down to $250^{\circ} \mathrm{C}$ (Fig. S9) which was due to the lowering of catalytic activity.

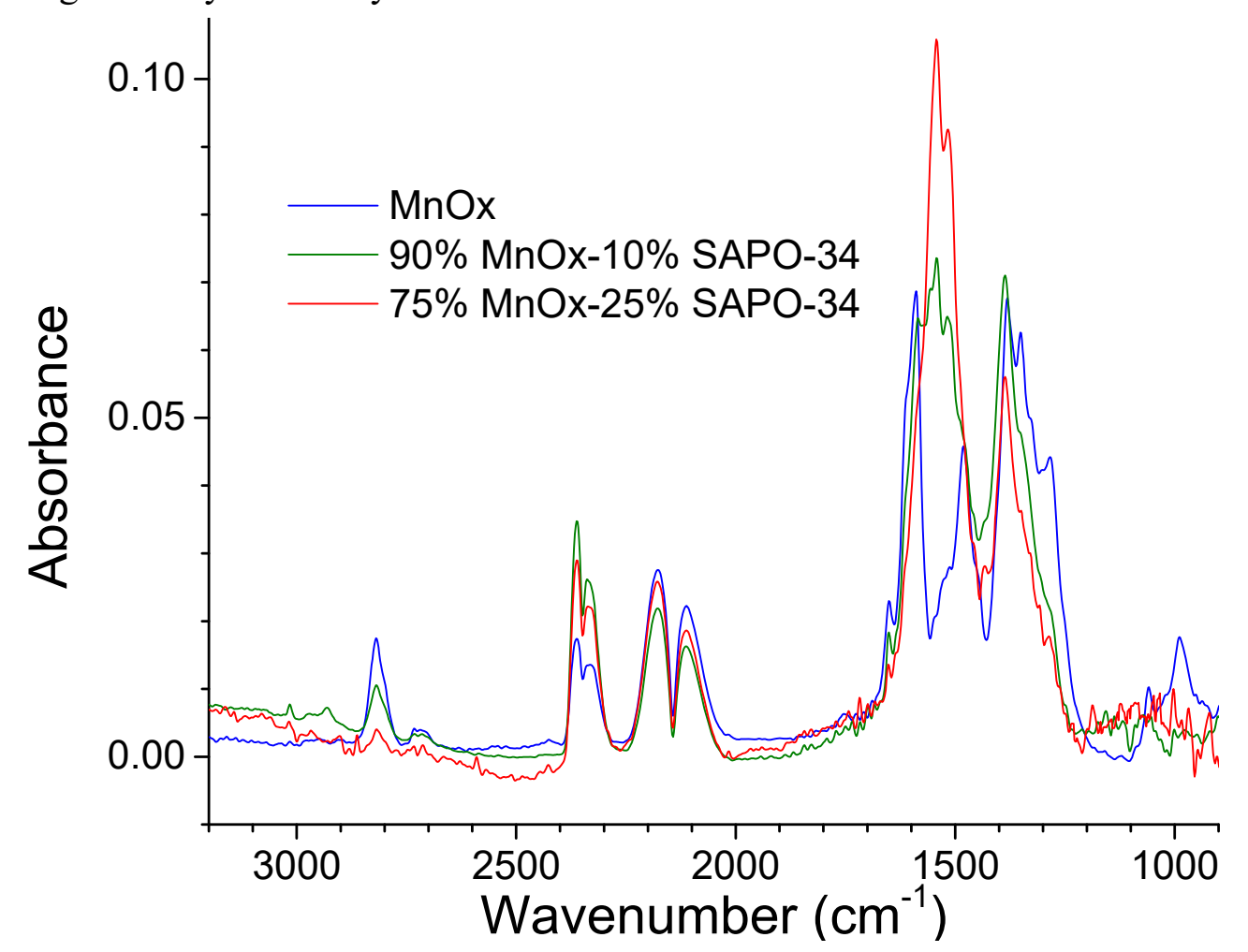

Fig.4 In situ DRIFT spectra of $\mathrm{MnO}_{\mathrm{x}}, 90 \% \mathrm{MnO}_{\mathrm{x}}-10 \% \mathrm{SAPO}-34$ and $75 \% \mathrm{MnO}_{\mathrm{x}}-25 \% \mathrm{SAPO}-34$ samples recorded at $410{ }^{\circ} \mathrm{C}$ after $10 \mathrm{~min}$ under $20 \mathrm{~mL} \cdot \mathrm{min}^{-1}$ of $2.5 \% \mathrm{CO} / 7.5 \% \mathrm{H}_{2} / 90 \% \mathrm{He}$ flow. The backgrounds corresponded to the spectra recorded under $20 \mathrm{~mL} \cdot \mathrm{min}^{-1}$ of $\mathrm{He}$ flow at $410{ }^{\circ} \mathrm{C}$ and activation at $430{ }^{\circ} \mathrm{C}$ under $20 \mathrm{~mL} \cdot \mathrm{min}^{-1} \mathrm{H}_{2}$ flow for $30 \mathrm{~min}$.

\section{Conclusions}

In this study, the reaction of $\mathrm{H}_{2} / \mathrm{CO}$ over $\mathrm{MnO}_{\mathrm{x}}$ was shown to produce methanol in addition to $\mathrm{CH}_{4}, \mathrm{CO}_{2}$ and $\mathrm{C} 2-\mathrm{C} 5$ hydrocarbons. When SAPO-34 is present as an additional catalytic bed, methanol is converted to $\mathrm{C} 2+$ hydrocarbons. The $\mathrm{CH}_{4}$ selectivity is then decreased suggesting it is formed by hydrogenation of methanol. A similar phenomenon was evidenced for $\mathrm{MnO}_{\mathrm{x}} / \mathrm{SAPO}-34$ mechanical mixtures.

In situ DRIFT measurements achieved on $\mathrm{MnO}_{\mathrm{x}}$ under $\mathrm{CO}$ at low temperature revealed a reactive adsorption phenomenon leading to formation of strong carbonates. Differently, in situ DRIFT 
spectra under $\mathrm{H}_{2} / \mathrm{CO}$ flow at the reaction temperature evidenced the presence of formates. Addition of SAPO-34 in mechanical mixture with $\mathrm{MnO}_{\mathrm{x}}$ leads to consumption of formates in agreement with consumption of methanol over SAPO-34 to form C2+ hydrocarbons.

Therefore, we proposed that methanol is a key reaction intermediate produced on $\mathrm{MnO}_{\mathrm{x}}$ that reacts with SAPO-34 to produce light olefins, which results in a synergistic effect between two catalytic functions.

\section{Conflicts of interest}

There are no conflicts to declare.

\section{Acknowledgment}

The French National Research agency 'Agence Nationale de la Recherche' (ANR) is acknowledged for the financial support of the INCH project (ANR-17-CE07-0011).

\section{References}

1 Gas-phase oxidation of alkanes, F. Cavani, A. Chieregato, J. M. Lopez Nieto, J.-M. M. Millet, Edited by A. J. L. Pombeiro, M. Guedes da Silva, C. Fatima Alkane Functionalization (2019), $159-188$.

2 A. K. Chandel, V. K. Garlapati, A. K. Singh, F. A. Fernandes Antunes, S. S. da Silva, Bioresour. Technol., 2018, 264, 370-381.

3 V. Hulea, ACS Catal., 2018, 8, 3263-3279.

4 T. K. Phung, T. L. M. Pham, K. B. Vu, G. Busca, J. Environ. Chem. Eng., 2021, 9, 105673.

5 D. Sun, Y. Li, C. Yang, Y. Su, Y. Yamada, S. Sato, Fuel Process. Technol., 2020, 197, 106193.

6 U. Olsbye, Angew. Chem. Int. Ed., 2016, 55, 7294-7295.

7 W. Zhou, K. Cheng, J. Kang, C. Zhou, V. Subramanian, Q. Zhang, Y. Wang, Chem. Soc. Rev., 2019, 48, 3193-3228.

8 F. Jiao, J. Li, X. Pan, J. Xiao, H. Li, H. Ma, M. Wei, Y. Pan, Z. Zhou, M. Li, S. Miao, J. Li, Y. Zhu, D. Xiao, T. He, J. Yang, F. Qi, Q. Fu, X. Bao, Science, 2016, 351, 1065-1068.

9 X. Pan, F. Jiao, D. Miao, X. Bao, Chem. Rev., 2021, 121, 6588-6609.

10 K. Cheng, B. Gu, X. Liu, J. Kang, Q. Zhang, Y. Wang, Angew. Chem. Int. Ed., 2016, 55, 47254728.

11 N. Li, F. Jiao, X. Pan, Y. Ding, J. Feng, X. Bao, ACS Catal., 2019, 9, 960-966.

12 Y. Huang, H. Ma, Z. Xu, W. Qian, H. Zhang, W. Ying, Fuel, 2020, 273, 117771. 
13 G. Li, F. Jiao, X. Pan, N. Li, D. Miao, L. Li, X. Bao, ACS Catal., 2020, 10, 12370-12375.

14 K. Pinkaew, G. Yang, T. Vitidsant, Y. Jin, C. Zeng, Y. Yoneyama, N. Tsubaki, Fuel, 2013, 111, $727-732$.

15 V. P. Santos, G. Pollefeyt, D. F. Yancey, A. Ciftci Sandikci, B. Vanchura, D.L.S. Nieskens, M. de Kok-Kleiberg, A. Kirilin, A. Chojecki, A. Malek, J. Catal., 2020, 381, 108-120.

16 L. Tan, F. Wang, P. Zhang, Y. Suzuki, Y. Wu, J. Chen, G. Yang, N. Tsubaki, Chem. Sci., 2020, 11, 4097-4105.

17 Y. Huang, H. Ma, Z. Xu, W. Qian, H. Zhang, W. Ying, ACS Omega, 2021, 6, 10953-10962.

18 Y. Huang, H. Ma, Z. Xu, W. Qian, H. Zhang, W. Ying, RSC Adv., 2021, 11, 13876-13883.

19 A. V. Kirilin, J. F. Dewilde, V. Santos, A. Chojecki, K. Scieranka, A. Malek, Ind. Eng. Chem. Res., 2017, 56, 13392-13401.

20 X. Liu, W. Zhou, Y. Yang, K. Cheng, J. Kang, L. Zhang, G. Zhang, X. Min, Q. Zhang, Y. Wang, Chem. Sci., 2018, 9, 4708-4718.

21 M. Wang, Z. Wang, S. Liu, R. Gao, K. Cheng, L. Zhang, G. Zhang, X. Min, J. Kang, Q. Zhang, Y. Wang, J. Catal., 2021, 394, 181-192.

22 Y. Ni, Y. Liu, Z. Chen, M. Yang, H. Liu, Y. He, Y. Fu, W. Zhu, Z. Liu, ACS Catal., 2019, 9, $1026-1032$.

23 G. Raveendra, C. Li, Y. Cheng, F. Meng, Z. Li, New J. Chem., 2018, 42, 4419-4431.

24 M. Wang, J. Kang, X. Xiong, F. Zhang, K. Cheng, Q. Zhang, Y. Wang, Catal. Today, 2021, 371, 85-92.

25 G. Raveendra, C. Li, B. Liu, Y. Cheng, F. Meng, Z. Li, Catal. Sci. Technol., 2018, 8, 3527-3538.

26 G. Raveendra, B. Ma, X. Liu, Y. Guo, Y. Wang, Catal. Sci. Technol., 2021, 11, 3231-3240.

27 X. Liu, M. Wang, H. Yin, J. Hu, K. Cheng, J. Kang, Q. Zhang, Y. Wang, ACS Catal., 2020, 10, 8303-8314.

28 Y. Luo, S. Wang, S. Guo, K. Yuan, H. Wang, M. Dong, Z. Qin, W. Fan, J. Wang, Catal. Sci. Technol., 2021, 11, 338-348.

29 F. Meng, X. Li, P. Zhang, L. Yang, G. Yang, P. Ma, Z. Li, Catal. Today, 2021, 368, 118-125.

30 F. Meng, X. Li, P. Zhang, L. Yang, S. Liu, Z. Li, Appl. Surf. Sci., 2021, 542, 148713.

31 S. Wang, P. Wang, D. Shi, S. He, L. Zhang, W. Yan, Z. Qin, J. Li, M. Dong, J. Wang, U. Olsbye,

W. Fan, ACS Catal., 2020, 10, 2046-2059.

32 Y. Zhu, X. Pan, F. Jiao, J. Li, J. Yang, M. Ding, Y. Han, Z. Liu, X. Bao, ACS Catal., 2017, 7, 2800 2804.

33 P. Zhang, F. Meng, X. Li, L. Yang, P. Ma, Z. Li, Catal. Sci. Technol., 2019, 9, 5577-5581. 
34 G. Yang, F. Meng, P. Zhang, L. Yang, Z. Li, New J. Chem., 2021, 45, 7967-7976.

35 J. Su, D. Wang, Y. Wang, H. Zhou, C. Liu, S. Liu, C. Wang, W. Yang, Z. Xie, M. He, ChemCatChem, 2018, 10, 1536 - 1541.

36 J. Su, H. Zhou, S. Liu, C. Wang, W. Jiao, Y. Wang, C. Liu, Y. Ye,

L. Zhang, Y. Zhao, H. Liu, D. Wang, W. Yang, Z. Xie, M. He, Nat. Commun., 2019, $10,1297$.

37 C.-M. Wang, Y.-D. Wang, Z.-K. Xie, Catal. Sci. Technol., 2016, 6, 6644-6649.

38 Z.-Q. Huang, T.-H. Li, B. Yang, C.-R. Chang, Chin. J. Catal., 2020, 41, 1906-1915.

39 R. Regmi, R. Tackett, G. Lawes, J. Magn. Magn. Mater., 2009, 321, 2296-2299.

40 J. Kaczmarczyk, F. Zasada, J. Janas, P. Indyka, W. Piskorz, A. Kotarba, Z. Sojka, ACS Catal., 2016,

6, 1235-1246.

41 T. Larbi, K. Doll, T. Manoubi, J. Alloys Compd. 2016, 688, 692-698.

42 H-h. Chou and H. Y. Fan, Phys. Rev. B, 1976, 13, 3924-3938.

43 Y. Mita, Y. Sakai, D. Izaki, M. Kobayashi, S. Endo, S. Mochizuki, Phys. Stat. Sol. (b) 2001, 223, $247-251$.

44 N. Mironova-Ulmanea, A. Kuzmina, V. Skvortsovaa, G. Chikvaidzea, I. Sildosb, J. Grabisc, D. Jankovicac, A. Dindunec, M. Maiorov, Acta Phys. Pol. A, 2018, 133, 1013-1016.

45 A. E. Berkowitz, G. F. Rodriguez, J. I. Hong, K. An, T. Hyeon, N. Agarwal, D. J. Smith, E. E. Fullerton, J. Phys. D: Appl. Phys. 2008, 41, 134007.

46 A. A. Tsyganenko, V. N. Filimonov, J. Mol. Struct., 1973, 19, 579-589.

47 J. C. Lavalley, Catal. Today 1996, 27, 377-401.

48 A. Goguet, F. C. Meunier, D. Tibiletti, J. P. Breen, R. Burch, J. Phys. Chem. B, 2004, 108, $20240-$ 20246.

49 G. Bor, G. Sbrignadello, J. Chem. Soc., Dalton Trans., 1974, 440-448.

50 R. E. Wittrig, C. P. Kubiak, J. Electroanal. Chem., 1995, 393, 75-86.

51 D. A. Steinhurst, A. P. Baronavski, J. C. Owrutsky, Chem. Phys. Lett., 2002, 361, 513-519.

52 G. Busca, J. Lamotte, J.-C. Lavalley, V. Lorenzelli, J. Am. Chem. Soc., 1987, 109, 5197-5202.

53 C. Li, Y. Sakata, T. Arai, K. Domen, K.-I. Maruya, T. Onishi, J. Chem. Soc., Faraday Trans. 1, 1989, 85, 1451-1461.

54 J. P. Durand, S. D. Senanayake, S. L. Suib, D. R. Mullins, J. Phys. Chem. C, 2010, 114, 2000020006.

55 L. Sivachandiran, F. Thevenet, A. Rousseau, Plasma Chem Plasma Process, 2013, 33, 855-871.

56 M. Daturi, C. Binet, J.-C. Lavalley, A. Galtayries, R. Sporken, Phys. Chem. Chem. Phys., 1999, 1, $5717-5724$. 
57 C. Li, K. Domen, K.-I. Maruya, T. Onishi, J. Catal., 1990, 125, 445-455.

58 F. Ouyang, J. N. Kondo, K.-I. Maruya, K. Domen, J. Phys. Chem. B, 1997, 101, 4867-4869.

59 G. N. Vayssilov, M. Mihaylov, P. St. Petkov, K. I. Hadjiivanov, K. M. Neyman, J. Phys. Chem. C, 2011, 115, 23435-23454. 